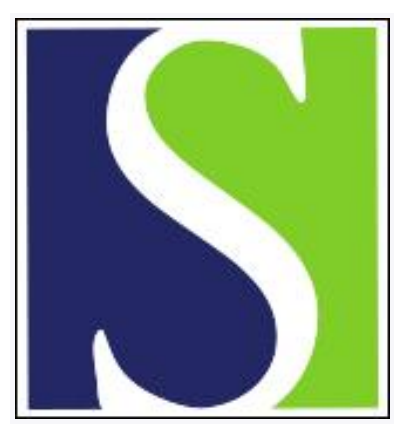

Scand J Work Environ Health 1998;24(1):62-73

https://doi.org/10.5271/sjweh.279

Issue date: Feb 1998

Computer mouse position as a determinant of posture, muscular load and perceived exertion

by Karlqvist LK, Bernmark E, Ekenvall L, Hagberg M, Isaksson A, Rostö $\mathrm{T}$

Key terms: arm support; electromyography; input device; macreflex motion analysis system; subjective rating; upper limb; video display unit

This article in PubMed: www.ncbi.nlm.nih.gov/pubmed/9562402

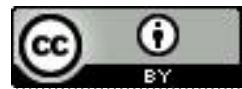




\title{
Computer mouse position as a determinant of posture, muscular load and perceived exertion
}

\author{
by Lena K Karlqvist, PhD, ${ }^{1,2}$ Eva Bernmark, MSc, ${ }^{1}$ Lena Ekenvall, MD, ${ }^{1}$ Mats Hagberg, MD, ${ }^{3,4}$ \\ Anita Isaksson, ${ }^{3}$ Tommy Rostö, MSc ${ }^{1}$
}

\begin{abstract}
Karlqvist LK, Bernmark E, Ekenvall L, Hagberg M, Isaksson A, Rostö T. Computer mouse position as a determinant of posture, muscular load and perceived exertion. Scand J Work Environ Health 1998:24(1):62-73.
\end{abstract}

\begin{abstract}
Objectives This study concerned the influence of 6 positions of the computer mouse on the work table on posture, muscular load, and perceived exertion during text editing.

Methods An optoelectronic 3-dimensional motion analysis system was used to register the postures of 10 men and 10 women using video display units. Muscular load was also registered (with electromyography), as was perceived exertion (with rating scales).

Results A neutral posture with a relaxed and supported arm showed the least perceived exertion, and the electromyographic results showed low activity in both trapezius muscles in this position. Short operators (all women) showed a numerically higher activity in the 4 examined muscles than the tall operators (all men, except 1). This finding could be related to lower muscle force among women and to anthropometric differences, which also influence biomechanic load moments. Narrow-shouldered operators ( 8 women and 1 man) and short operators worked with larger outward rotation and abduction of the shoulder in a position of the mouse lateral to the keyboard than the broad-shouldered ( 7 men and 2 women) and tall operators did. Arm support markedly reduced muscle load in the neck-shoulder region among the operators.

Conclusions The operators using video display units in this study preferred to use the mouse on a table in a close to relaxed, neutral posture of the arm in combination with arm support. Short and narrow-shouldered operators worked in more strenuous postures of the arm when the mouse was located lateral to the keyboard.
\end{abstract}

Key terms arm support, electromyography, input device, MacReflex motion analysis system, subjective ratings, upper limb, video display unit.

In recent years, the occurrence of cumulative trauma disorders such as carpal tunnel syndrome and tendinitis has increased dramatically in the United States, and these diseases account for over $60 \%$ of occupational illnesses (1). Video display terminal users have reported musculoskeletal symptoms primarily in the upper limbs, neck, and shoulders (2, 3). Health problems during work with video display terminals have been reported also in Sweden $(4,5)$.

The computer mouse and other nonkeyboard input devices supplement the keyboard in many visual display unit (VDU) workstations. The mouse technique changes posture and movements compared with keyboard use without the mouse (6). Franzblau et al (7) found the incidence of carpal tunnel syndrome to be related to the pattern of mouse usage in a medical illustration department.

Associations between self-reported neck and upper-limb symptoms and physical exposure factors at VDU workstations have recently been investigated (8). The study showed that long hours of work with the mouse, as well as work with the mouse nonoptimally located on the table, seem to be risk factors for upper-limb symptoms.

Several significant relationships between the design of workstations or postures on one hand and the incidence of complaints or medical findings on the other have been discovered among VDU operators using a keyboard $(3,4,9)$. Schuildt et al (10) found that arm support or arm suspension

1 Department of Occupational Health, Karolinska Hospital, Stockholm, Sweden.

2 Department of Surgical Sciences K3, Section of Rehabilitation Medicine, Karolinska Institute and Hospital, Stockholm, Sweden.

3 Department of Ergonomics, National Institute for Working Life, Solna, Sweden.

4 Department of Occupational Medicine, Gothenburg University, Sahlgrenska University Hospital, Göteborg, Sweden.

Reprint requests to: Dr Lena Karlqvist, Department of Occupational Health, NVSO, Karolinska Hospital, S-171 76 Stockholm, Sweden. [e-mail: lenkar@ymed.ks.se] 
can be used to reduce neck muscle load. However, no reports have been found regarding the location of nonkeyboard input devices for computers on the worktable in relation to posture, arm support, and muscular load.

The aim of the present study was therefore to study posture, muscular load, and perceived exertion for different positions of the mouse during text editing.

\section{Subjects and methods}

\section{Subjects}

Twenty healthy computer operators, 10 men and 10 women, volunteered to participate in the study. They were all professional computer users, working with the window technique and using a mouse or a track-ball beside the keyboard. The mean age of the men was 41 (range 29-49) years, and for the women it was 47 (range 30-56) years (table 1). The men were taller and heavier than the women. The median worktime was 40 hours a week in both groups, and both groups also reported similar experience with mouse and track-ball use, an average of 6 and 5 years, respectively. They mainly used software such as Word, Excel, Canvas, and Delta Graph. All the subjects used their right hand for the nonkeyboard computer input device. They were all informed of the objective of the study and the study design. On the day of the measurements, more-detailed information was given, and everyone received a personal presentation of the procedure and the questionnaires to be filled out.

This study was approved by the Ethics Committee of the Karolinska Institute, Stockholm.

\section{Experimental set-up}

The study was performed in a laboratory with a modern, adjustable workstation. The desk and the chair were easy to modify for differences in anthropometric data among the subjects who adjusted the heights and work positions them- selves. The chair had 2 ordinary, removable armrests and the subjects could choose to use them or not, according to their former habits. The lighting was adapted for this purpose, and there was a manuscript holder. The mouse used was from Apple $^{\circledR}$ (BusMouse II), and the computer was a Macintosh II Si with MS Word 4.0 software.

All the subjects corrected a given text during 2 minutes in each of 6 mouse positions (figure 1 ). The testing sequence of the 6 mouse position alternatives was randomized. The subjects were instructed to keep the center of the mouse as close as possible within each of the set 6 positions when correcting the given text. The screen of the computer was in a fixed position; it was placed at a distance of $0.5 \mathrm{~m}$ from the front edge of the work table and the height from the work table surface to the mid-point of the screen was $0.3 \mathrm{~m}$. After all the subjects had adjusted the workstation, we compared its dimensions with the anthropometric data (table 1).

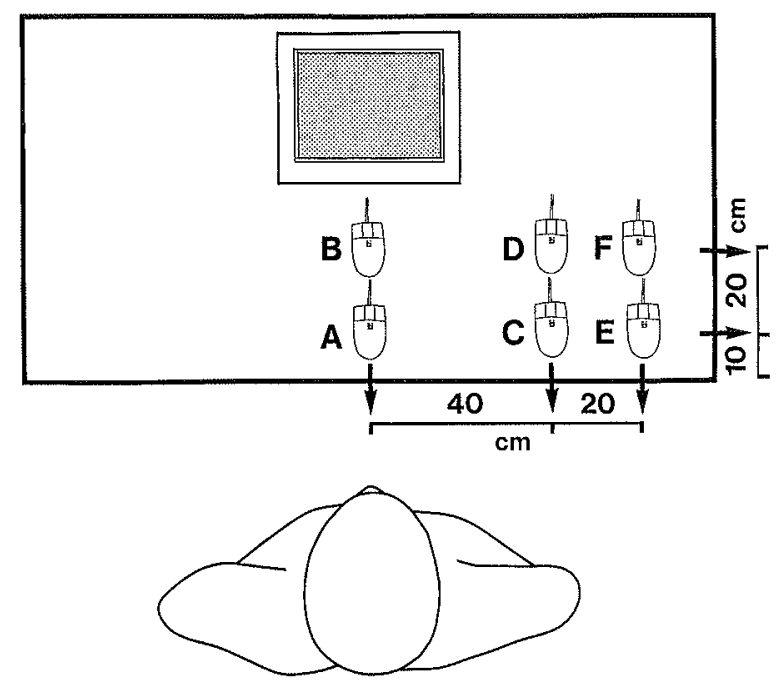

Figure 1. Location of the mouse on the work table when performing text editing at 6 different positions $(A-F)$.

Table 1. Participating subjects, anthropometric data, and workstation dimensions. (VDU = visual display unit)

\begin{tabular}{|c|c|c|c|c|}
\hline & \multicolumn{2}{|c|}{$\operatorname{Men}(N=10)$} & \multicolumn{2}{|c|}{ Women $(N=10)$} \\
\hline & Mean & Range & Mean & Range \\
\hline $\begin{array}{l}\text { Age (years) } \\
\text { Stature (cm) } \\
\text { Shoulder breadth (biacromial) (cm) } \\
\text { Body weight (kg) } \\
\text { Workhours/week } \\
\text { VDU work as percentage of workday } \\
\text { VDU work experience (months) }\end{array}$ & $\begin{array}{c}41 \\
182 \\
42 \\
81 \\
40.2 \\
49 \\
114\end{array}$ & $\begin{array}{c}29-49 \\
172-191 \\
37-45 \\
70-101 \\
32-50 \\
30-84 \\
6-264\end{array}$ & $\begin{array}{l}47 \\
166 \\
37 \\
60 \\
37.6 \\
43 \\
100\end{array}$ & $\begin{array}{l}30-56 \\
156-173 \\
33-43 \\
45-82 \\
30-42 \\
20-70 \\
26-324\end{array}$ \\
\hline $\begin{array}{l}\text { Sitting height }(\mathrm{cm}) \\
\text { Eye height }(\mathrm{cm}) \\
\text { Shoulder height }(\mathrm{cm}) \\
\text { Elbow height }(\mathrm{cm}) \\
\text { Popliteal height }(\mathrm{cm})\end{array}$ & $\begin{array}{r}136 \\
125 \\
108 \\
69 \\
48\end{array}$ & $\begin{array}{c}126-144 \\
116-132 \\
101-114 \\
66-73 \\
44-53\end{array}$ & $\begin{array}{r}125 \\
116 \\
98 \\
62 \\
43\end{array}$ & $\begin{array}{c}120-135 \\
108-125 \\
92-108 \\
58-72 \\
39-47\end{array}$ \\
\hline $\begin{array}{l}\text { Chair height (cm) } \\
\text { Table height (cm) } \\
\text { Work surface below }(-) \\
\text { or above }(+) \text { elbow height }\end{array}$ & $\begin{array}{r}52 \\
74 \\
0\end{array}$ & $\begin{array}{l}50-55 \\
70-76 \\
-5-+4\end{array}$ & $\begin{array}{r}49 \\
71 \\
3\end{array}$ & $\begin{array}{l}45-54 \\
70-71 \\
-5-+9\end{array}$ \\
\hline
\end{tabular}




\section{Postures}

To document body postures, video recordings were made in the sagittal plane during the whole measuring time. Postures of the neck, shoulder, elbow, and wrist of the right side were registered with an optoelectronic 3-dimensional (3D) motion analysis system, the MacReflex system, version 3.0 (Qualisys, Göteborg, Sweden); 4 cameras with video processors, a Macintosh computer, and 11 markers attached to the subject were used for this purpose (figure 2).

The camera system records the reflective markers and delivers 2-dimensional (2D) information about their positions. Each camera is equipped with a built-in invisible infrared light. The video processor processes the image from the camera, calculates 2D marker coordinates, and delivers the coordinates to the Macintosh computer. The MacReflex software reads data from the camera system, processes it, and then converts it to a format suitable for data-processing programs.

All 11 markers attached to the study subjects were recorded by at least 2 cameras at a time. Markers 1 to 4 (head, neck, shoulder, elbow) (figure 2) were recorded by cameras 1,2 , and 4 and markers 5 to 11 (forearm, reference coordinate system, wrist, hand surface, mouse) (figure 2) were seen by camera 3 and at least 1 of the other 3 cameras. The sampling frequency was set at $10 \mathrm{~Hz}$.

After the subject had adjusted his or her workstation, the MacReflex measurement system was calibrated with a calibration reference frame. The frame had a size that covered the field of view for all cameras, had 6 markers, and was placed on the work table during the calibration procedure.

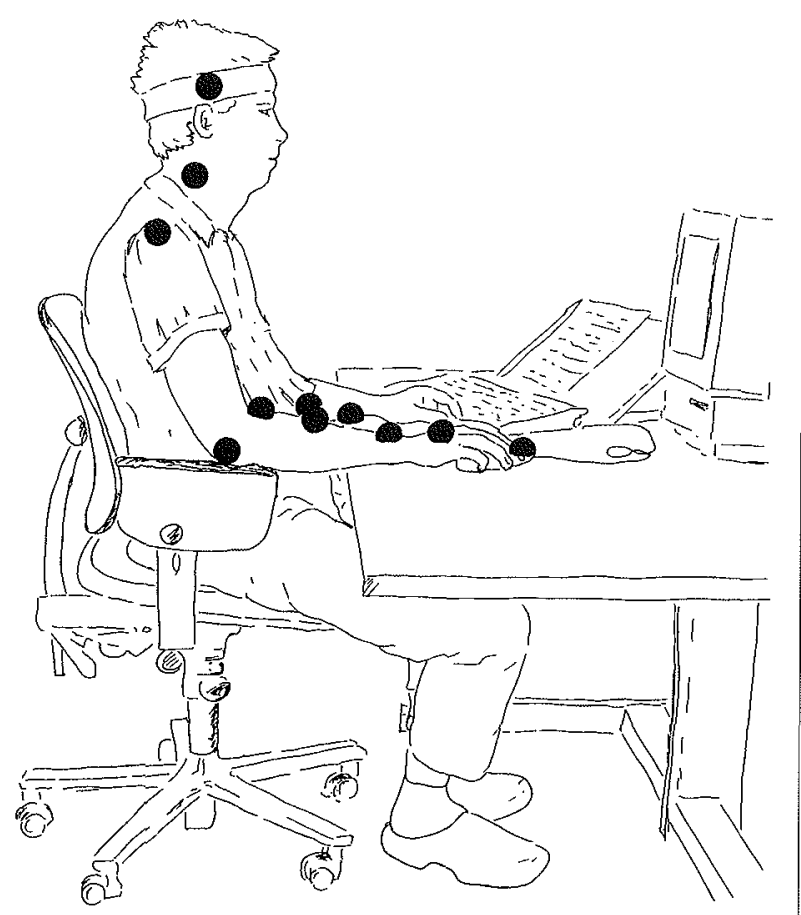

Figure 2. Placement of 11 markers attached to the subject.
Just before the registrations, the subject's reference posture was recorded as a starting position (upright sitting, looking straight ahead with an angle of $90^{\circ}$ for elbows, and palms on the edge of the table). So that registrations could be made of all 11 markers with all 4 cameras, the subjects leaned down towards the table. This action was repeated for each of the 6 mouse positions in order to minimize any marker sorting problem.

After the markers were sorted, all the data were transferred to Excel 5.0 for the calculations.

Flexion was calculated for the neck, the right shoulder, the right elbow, and the right wrist. The abduction and rotation of the right shoulder and the deviation of the right wrist were also calculated. Postures and joint motion were defined according to the recommendations of the American Academy of Orthopedic Surgeons (11). Negative values were used for angles of extension and inward rotation of the shoulder and radial deviation and flexion of the wrist.

\section{Muscular load}

A digital telemetric ME4001 electromyographic (EMG) analysis system (Mega Electronics Ltd, Finland) was used for measuring EMG muscle activity. Surface electrodes (Medicotest A-10-S) were placed in pairs with a $30-\mathrm{mm}$ center distance upon carefully prepared skin over the studied muscles (12). All the electrodes were positioned by the same person.

Muscular activity was studied from the left trapezius, pars descendens (midpoint between the 2 electrodes $10 \mathrm{~mm}$ lateral to half the distance between C7 and the acromion) (13), the right trapezius, pars descendens (midpoint between the 2 electrodes $10 \mathrm{~mm}$ lateral to half the distance between $\mathrm{C} 7$ and the acromion), the right deltoid (front part), and the right extensor digitorum (midpoint between the 2 electrodes onethird of the distance between the lateral epicondyle and the lateral styloid process).

So that the EMG base-line values could be determined, the subject relaxed for $30 \mathrm{~s}$ before the registration with the 6 positions of the mouse and again after finishing the last test. At the beginning of the recordings the subject performed standardized maximal contractions to obtain the maximal voluntary electrical activity of all relevant muscles (14). This procedure was done against manual resistance and performed by the same person every time.

The raw EMG signal was the root mean square (RMS) detected at a time constant of $100 \mathrm{~ms}$. Data were collected with a BioPac, Qualisys Synchronized Unit, for which the EMG signals were synchronized with MacReflex measurements. EMG data from the BioPac were then transferred to a Macintosh computer for editing in the AcqKnowledge program.

\section{Subjective ratings}

After finishing the work in each mouse position, the subjects rated their perceived exertion in the shoulder and hand-forearm region and also their general comfort. This rating was 
done by comparing the latest mouse position with the previous one (ie, the position used in the preceding test). During the comparison, the previous mouse position was always set $\mathrm{a} 0$ on a scale running from -4 , much worse, to +4 , much better. The ratings from each subject were normed from position $A=0$ when the positions were compared. The preferred position of the mouse was noted.

\section{Statistics}

As the data were approximately normally distributed, all the descriptive data have been presented as means with the standard deviations or ranges. The results of 2 male subjects were excluded in the analysis of postures and muscular load due to technical recording errors. Median stature $(171 \mathrm{~cm})$ and shoulder breadth $(39 \mathrm{~cm})$ were used when comparisons between data from different mouse positions were analyzed by a 2-way analysis of variance for repeated measurements. Stature or shoulder breadth and position were used as independent variables (SuperANOVA ${ }^{\circledR}$ ). P-values less than 0.05 were considered statistically significant. When single mouse positions for tall or short subjects and subjects with narrow or broad shoulders were compared (joint positions, muscles), $95 \%$ confidence intervals $(95 \% \mathrm{CI}$ ) were calculated with the $t$-distribution for the differences between the means (15).

\section{Results}

\section{Postures}

All the joint positions studied, except wrist deviation, changed significantly with mouse position. (See the appendix.) Shoulder abduction and shoulder elevation also showed interaction between position and stature (ie, the effects of the positions were not the same for the tall and short subjects). Work with the hand out to the side (positions E and F, figure 1) led to large outward rotation and abduction in the shoulder for all the operators (table 2). Shoulder rotation differed between the tall and the short subjects in positions $A$, $\mathrm{D}$, and $\mathrm{E}$ and between subjects with broad and narrow shoulders in positions A, C, E, and F. (See the appendix.) The tall and the broad-shouldered subjects worked with larger inward rotation in position $A$ and less outward rotation in positions $\mathrm{C}, \mathrm{D}, \mathrm{E}$, and $\mathrm{F}$ than the short and the narrow-shouldered subjects (table 2). Shoulder abduction also differed between the tall and broad-shouldered and the short and narrow-shouldered subjects in position $\mathrm{D}$, where the short and narrowshouldered subjects worked with larger abduction (table 2). Shoulder flexion in position $\mathrm{A}$ and $\mathrm{E}$ also differed between the same groups. The short and the narrow-shouldered subjects extended the shoulder backwards and the tall and the broad-shouldered subjects flexed it forward (table 2). Shoulder elevation differed among the 6 positions for the short and the narrow-shouldered subjects. With the hand in front of the body (in position B), the short and the narrow-shouldered subjects lifted their right shoulder. The average shoulder elevation of the short subjects was $10 \mathrm{~mm}$ higher than in their reference posture, and for the tall subjects it was $16 \mathrm{~mm}$ lower.

\section{Muscular load}

Muscular activity in the right trapezius and the deltoid muscles changed significantly with mouse position. (See the appendix.) In the deltoid muscle the activity differed significantly between the tall and short subjects, and there were no interactions between position and stature.

The short subjects showed numerically higher activity in the 4 examined muscles than the tall subjects did across all positions. The $95 \%$ confidence interval showed statistical significance between the tall and short subjects in position $B$ (the right trapezius, the deltoid, and the extensor digitorum muscles) and positions D, E, and F (the deltoid muscle) (table 3 ). The left trapezius muscle had activity similar to that in the right trapezius muscle although all the subjects used the right hand to operate the mouse.

The video recordings showed that all 9 tall subjects supported their right arm against the table or the armrest of the chair in position D, 8 supported it in position $\mathrm{B}$, and 6 in position F. Eight of the 9 short subjects supported their right arm in positions D and F. Out of a total of 40 different work sessions with a supported right arm, 32 also demonstrated the lowest percentage of maximal voluntary electrical activity in the right trapezius muscle.

The analysis of the anthropometric data and workstation dimensions showed that 10 subjects adjusted the work surface to 0.03 to $0.09 \mathrm{~m}$ above elbow height during their work. The other 10 subjects chose a work surface of less than $0.03 \mathrm{~m}$ above their elbow height. The EMG results showed lower activity $(\mathrm{P}<0.0001)$ in both trapezius muscles and the deltoid muscle among the subjects who had chosen the work surface to be less than $0.03 \mathrm{~m}$ above their elbow height.

The activity in the right extensor digitorum muscle did not differ between the mouse positions or with the work surface height.

\section{Subjective ratings}

Seven of the tall operators and 5 of the short operators experienced the most comfort in position $\mathrm{D}$. Perceived exertion in the shoulder and in the hand-forearm showed a similar pattem.

The preference was highest for position $\mathrm{D}$ ( 8 operators) followed by $\mathrm{C}, \mathrm{B}$, and $\mathrm{F}$. No person preferred position $\mathrm{E}$.

\section{Discussion}

The fixed mouse positions in our study were selected from experience in field studies $(16,17)$. Design work is often performed on a fixed table immediately in front of the opera- 
Table 2. Mean joint positions during work with the mouse in 6 different mouse positions (A-F). Measured in degrees. $(95 \% \mathrm{Cl}=95 \%$ con

\begin{tabular}{|c|c|c|c|c|c|c|c|}
\hline & \multirow[t]{2}{*}{$N$} & \multicolumn{3}{|c|}{ A } & \multicolumn{3}{|c|}{ B } \\
\hline & & Mean & SD & $95 \% \mathrm{Cl}$ & Mean & SD & $95 \% \mathrm{Cl}$ \\
\hline \multicolumn{8}{|l|}{ Neckflexion } \\
\hline Tall subjects & 9 & 27 & 7.1 & \multirow{2}{*}{$-1.05-13.0$} & 28 & 9.3 & \multirow{2}{*}{$-0.294-18.3$} \\
\hline Short subjects & 9 & 21 & 7.0 & & 19 & 9.3 & \\
\hline \multicolumn{8}{|l|}{ Shoulder rotation } \\
\hline Tall subjects & 9 & -41 & 11.6 & \multirow{2}{*}{$-25.7-2.31$} & -29 & 7.8 & \multirow{2}{*}{$-14.7-2.69$} \\
\hline Short subjects & 9 & -27 & 11.8 & & -23 & 9.5 & \\
\hline \multicolumn{8}{|c|}{ Shoulder abduction } \\
\hline Tall subjects & 9 & 17 & 10.2 & \multirow{2}{*}{$-10.4-6.40$} & 15 & 10.5 & \multirow{2}{*}{$-13.0-5.04$} \\
\hline Short subjects & 9 & 19 & 6.1 & & 19 & 7.3 & \\
\hline \multicolumn{8}{|l|}{ Shoulder flexion } \\
\hline Tall subjects & 9 & 0.4 & 10.7 & \multirow{2}{*}{$-4.39-17.2$} & 18 & 10.5 & \multirow{2}{*}{$-10.3-16.3$} \\
\hline Short subjects & 9 & -6 & 10.9 & & 15 & 15.7 & \\
\hline \multicolumn{8}{|l|}{ Wrist extension } \\
\hline Tall subjects & 9 & 23 & 5.1 & \multirow{2}{*}{$-3.30-7.30$} & 17 & 4.6 & \multirow{2}{*}{$-6.96-2.96$} \\
\hline Short subjects & 9 & 21 & 5.5 & & 19 & 5.3 & \\
\hline \multicolumn{8}{|l|}{ Wrist deviation } \\
\hline Tall subjects & 9 & 11 & 9.0 & \multirow{2}{*}{$-7.09-11.1$} & 10 & 5.2 & \multirow{2}{*}{$-6.61-4.61$} \\
\hline Short subjects & 9 & 9 & 9.2 & & 11 & 6.0 & \\
\hline \multicolumn{8}{|l|}{ Elbow flexion } \\
\hline Tall subjects & 9 & 75 & 10.1 & \multirow{2}{*}{$-1.78-13.8$} & 95 & 14.9 & \multirow{2}{*}{$-8.79-18.8$} \\
\hline Short subjects & 9 & 69 & 4.4 & & 90 & 12.6 & \\
\hline \multicolumn{8}{|c|}{$\begin{array}{l}\text { Shoulder elevation ( } \mathrm{mm} \text { ) as difference between } \\
\text { reference value and positions }\end{array}$} \\
\hline Tall subjects & 9 & -13 & 24.9 & \multirow{2}{*}{$-30.1-10.1$} & -16 & 9.5 & \multirow{2}{*}{$-39.5--12.5$} \\
\hline Short subjects & 9 & -3 & 13.7 & & 10 & 16.5 & \\
\hline
\end{tabular}

Table 3. Mean muscular activity (percentage of maximal voluntary electrical activity) during work with the mouse in 6 different positions (A-F).

\begin{tabular}{|c|c|c|c|c|c|c|c|}
\hline & \multirow[t]{2}{*}{$N$} & \multicolumn{3}{|c|}{$B$} & \multicolumn{3}{|c|}{$B$} \\
\hline & & Mean & $\mathrm{SD}$ & $95 \% \mathrm{Cl}$ & Mean & SD & $95 \% \mathrm{Cl}$ \\
\hline \multicolumn{8}{|l|}{ Left trapezius } \\
\hline Tall subjects & 9 & 4.0 & 3.4 & \multirow{2}{*}{$-7.29-2.09$} & 3.2 & 2.7 & \multirow{2}{*}{$-11.8-2.18$} \\
\hline Short subjects & 9 & 6.6 & 5.7 & & 8.0 & 9.5 & \\
\hline \multicolumn{8}{|l|}{ Right trapezius } \\
\hline Tall subjects & 9 & 2.9 & 2.7 & \multirow{2}{*}{$-10.6-0.799$} & 2.3 & 0.8 & \multirow{2}{*}{$-17.8--0.390$} \\
\hline Short subjects & 9 & 7.8 & 7.6 & & 11.4 & 12.3 & \\
\hline \multicolumn{8}{|l|}{ Right deltoid } \\
\hline Tall subjects & 9 & 0.9 & 0.7 & \multirow{2}{*}{$-3.40-0.403$} & 2.0 & 3.1 & \multirow{2}{*}{$-7.55--1.75$} \\
\hline Short subjects & 9 & 2.4 & 2.6 & & 4.9 & 5.8 & \\
\hline \multicolumn{8}{|c|}{ Right extensor digitorum } \\
\hline Tall subjects & 9 & 6.9 & 3.6 & \multirow{2}{*}{$-4.51-1.11$} & 6.1 & 2.3 & \multirow{2}{*}{$-5.46--1.34$} \\
\hline Short subjects & 9 & 8.6 & 1.7 & & 9.5 & 1.8 & \\
\hline
\end{tabular}

tor, where a mouse is used to click on several objects (position $\mathrm{A}$ and $\mathrm{B}$ in our study). Most computer operators have a keyboard located on the table in front of them and have to place the mouse further away and lateral to the keyboard (po- sition $\mathrm{C}$ and $\mathrm{D}$ ). However, many operators put the mouse even further away on the table (position $\mathrm{E}$ and $\mathrm{F}$ ).

It is easier to support the arm against the work surface when the table is higher than elbow height $(5,18)$. On the 
fidence interval)

\begin{tabular}{|c|c|c|c|c|c|c|c|c|c|c|c|}
\hline \multicolumn{3}{|c|}{$\mathrm{C}$} & \multicolumn{3}{|c|}{$\mathrm{D}$} & \multicolumn{3}{|c|}{$E$} & \multicolumn{3}{|c|}{$\mathrm{F}$} \\
\hline Mean & SD & $95 \% \mathrm{Cl}$ & Mean & $\mathrm{SD}$ & $95 \% \mathrm{Cl}$ & Mean & SD & $95 \% \mathrm{Cl}$ & Mean & SD & $95 \% \mathrm{Cl}$ \\
\hline $\begin{array}{l}26 \\
22\end{array}$ & $\begin{array}{l}7.9 \\
8.0\end{array}$ & $-3.94-11.9$ & $\begin{array}{l}26 \\
25\end{array}$ & $\begin{array}{l}7.9 \\
5.1\end{array}$ & $-5.64-7.64$ & $\begin{array}{l}29 \\
25\end{array}$ & $\begin{array}{l}4.1 \\
5.7\end{array}$ & $-0.962-8.96$ & $\begin{array}{l}29 \\
24\end{array}$ & $\begin{array}{l}6.2 \\
6.1\end{array}$ & $-1.15-11.1$ \\
\hline $\begin{array}{l}18 \\
26\end{array}$ & $\begin{array}{r}9.2 \\
11.0\end{array}$ & $-18.1-2.13$ & $\begin{array}{l}16 \\
23\end{array}$ & $\begin{array}{l}6.2 \\
4.9\end{array}$ & $-12.6--1.42$ & $\begin{array}{l}41 \\
52\end{array}$ & $\begin{array}{l}6.9 \\
9.5\end{array}$ & $-19.3--2.70$ & $\begin{array}{l}36 \\
40\end{array}$ & $\begin{array}{l}6.2 \\
5.7\end{array}$ & $9.95-1.95$ \\
\hline $\begin{array}{l}23 \\
20\end{array}$ & $\begin{array}{l}8.4 \\
4.4\end{array}$ & $-3.70-9.70$ & $\begin{array}{l}21 \\
33\end{array}$ & $\begin{array}{r}6.9 \\
11.7\end{array}$ & $-21.6--2.40$ & $\begin{array}{l}34 \\
34\end{array}$ & $\begin{array}{r}14.4 \\
7.8\end{array}$ & $-11.6-11.6$ & $\begin{array}{l}31 \\
37\end{array}$ & $\begin{array}{r}12.7 \\
7.0\end{array}$ & $-16.2-4.25$ \\
\hline $\begin{array}{l}-2 \\
-9\end{array}$ & $\begin{array}{l}11.5 \\
14.2\end{array}$ & $-5.91-19.9$ & $\begin{array}{l}10 \\
12\end{array}$ & $\begin{array}{r}6.4 \\
11.9\end{array}$ & $-11.5-7.35$ & $\begin{array}{r}6 \\
-5\end{array}$ & $\begin{array}{r}8.1 \\
11.8\end{array}$ & $0.886-21.1$ & $\begin{array}{l}13 \\
14\end{array}$ & $\begin{array}{r}13.2 \\
9.5\end{array}$ & $-12.5-10.5$ \\
\hline $\begin{array}{l}31 \\
27\end{array}$ & $\begin{array}{l}11.9 \\
14.7\end{array}$ & $-9.36-17.4$ & $\begin{array}{l}23 \\
23\end{array}$ & $\begin{array}{l}6.1 \\
4.2\end{array}$ & $-5.23-5.23$ & $\begin{array}{l}41 \\
26\end{array}$ & $\begin{array}{r}12.8 \\
6.6\end{array}$ & $4.82-25.2$ & $\begin{array}{l}25 \\
26\end{array}$ & $\begin{array}{r}7.0 \\
12.7\end{array}$ & $-11.2-9.25$ \\
\hline $\begin{array}{l}12 \\
10\end{array}$ & $\begin{array}{l}9.9 \\
9.9\end{array}$ & $-7.89-11.9$ & $\begin{array}{l}10 \\
10\end{array}$ & $\begin{array}{l}4.1 \\
6.4\end{array}$ & $-5.37-5.37$ & $\begin{array}{r}12 \\
6\end{array}$ & $\begin{array}{l}9.2 \\
5.9\end{array}$ & $-1.72-13.7$ & $\begin{array}{l}6 \\
7\end{array}$ & $\begin{array}{l}9.9 \\
7.2\end{array}$ & $-9.65-7.65$ \\
\hline $\begin{array}{l}95 \\
84\end{array}$ & $\begin{array}{r}13.7 \\
7.3\end{array}$ & $0.0305-22.0$ & $\begin{array}{l}101 \\
106\end{array}$ & $\begin{array}{r}10.9 \\
5.5\end{array}$ & $-13.6-3.63$ & $\begin{array}{l}112 \\
111\end{array}$ & $\begin{array}{l}23.0 \\
13.2\end{array}$ & $-17.7-19.7$ & $\begin{array}{l}117 \\
115\end{array}$ & $\begin{array}{r}18.2 \\
7.4\end{array}$ & $-11.9-15.9$ \\
\hline $\begin{array}{r}-10 \\
-6\end{array}$ & $\begin{array}{l}17.2 \\
10.7\end{array}$ & $-18.3-10.3$ & $\begin{array}{l}-21 \\
-15\end{array}$ & $\begin{array}{l}19.4 \\
12.0\end{array}$ & $-22.1-10.1$ & $\begin{array}{r}-10 \\
-7\end{array}$ & $\begin{array}{r}14.5 \\
9.5\end{array}$ & $-15.2-9.25$ & $\begin{array}{l}-28 \\
-35\end{array}$ & $\begin{array}{l}17.1 \\
15.4\end{array}$ & $-9.26-23.3$ \\
\hline
\end{tabular}

(95\% Cl $=95 \%$ confidence interval)

\begin{tabular}{|c|c|c|c|c|c|c|c|c|c|c|c|}
\hline \multicolumn{3}{|c|}{ C } & \multicolumn{3}{|c|}{ D } & \multicolumn{3}{|c|}{ E } & \multicolumn{3}{|c|}{$\mathrm{F}$} \\
\hline Mean & SD & $95 \% \mathrm{Cl}$ & Mean & SD & $95 \% \mathrm{Cl}$ & Mean & SD & $95 \% \mathrm{Cl}$ & Mean & SD & $95 \% \mathrm{Cl}$ \\
\hline 4.8 & 3.5 & \multirow{2}{*}{$-5.38-2.78$} & 3.9 & 3.5 & \multirow{2}{*}{$-3.85-3.05$} & 4.3 & 3.3 & \multirow{2}{*}{$-11.2-1.64$} & 3.6 & 2.5 & \multirow{2}{*}{$-3.75-0.953$} \\
\hline 6.1 & 4.6 & & 4.3 & 3.4 & & 9.1 & 8.5 & & 5.0 & 2.2 & \\
\hline 3.4 & 2.4 & \multirow{2}{*}{$-7.96-1.56$} & 2.0 & 1.9 & \multirow{2}{*}{$-5.40-0.602$} & 3.0 & 1.9 & \multirow{2}{*}{$-10.4-0.636$} & 1.3 & 1.2 & \multirow{2}{*}{$-5.92-0.119$} \\
\hline 6.6 & 6.3 & & 4.4 & 3.8 & & 7.9 & 7.6 & & 4.2 & 4.1 & \\
\hline 1.5 & 1.4 & \multirow{2}{*}{$-5.00-0.595$} & 1.3 & 1.1 & \multirow{2}{*}{$-7.56--2.24$} & 1.5 & 1.3 & \multirow{2}{*}{$-8.72--0.875$} & 1.3 & 0.6 & \multirow{2}{*}{$-6.19--0.612$} \\
\hline 3.7 & 3.7 & & 6.2 & 3.6 & & 6.3 & 5.4 & & 4.7 & 3.9 & \\
\hline 6.2 & 3.9 & \multirow{2}{*}{$-4.74-1.74$} & 6.4 & 2.1 & \multirow{2}{*}{$-4.15-0.149$} & 6.7 & 3.1 & \multirow{2}{*}{$-4.53-0.533$} & 6.8 & 2.4 & \multirow{2}{*}{$-2.75-1.95$} \\
\hline 7.7 & 2.4 & & 8.4 & 2.2 & & 8.7 & 1.8 & & 7.2 & 2.3 & \\
\hline
\end{tabular}

other hand, too high a work surface could increase the shoulder height and lead to a high muscular load in the trapezius muscles and cause discomfort (5). The EMG results showed a lower activity in both trapezius muscles and the deltoid muscle among the subjects who had chosen the work surface to be less than $0.03 \mathrm{~m}$ above elbow height. This finding agrees with that of studies of musculoskeletal load and biomechanical torque in the neck and shoulders $(10,19-21)$. 
Our results from the EMG and the video recordings indicated less shoulder muscle load during work in positions with the arm supported against the worktable or armrest than during work without support. This finding is consistent with the results of other experimental studies (10).

The analysis of work postures in the 6 different positions of the mouse indicated large outward rotation and abduction in the shoulder for all the operators in position $\mathrm{E}$ and $\mathrm{F}$. These postures cause high biomechanical torques in the neckshoulders (20), and they were also rated as the most uncomfortable. However, in position $F$, the operators demonstrated low muscular activity in the right trapezius muscle. This finding was probably due to the use of the arm support among most of the operators in this position (14 of the 18 operators) and a low shoulder height as a result of forward leaning of the trunk. A subjectively uncomfortable posture may thus be accompanied by low muscle activity. In position $\mathrm{E}$, where the mouse was used further away from the body, the wrist extension among the tall and broad-shouldered subjects was greater than in position $B$.

Position A implied large inward rotation in the shoulder for the tall and the broad-shouldered subjects. The short (all women) and the narrow-shouldered subjects ( 8 women and $1 \mathrm{man}$ ) worked with outward rotation in positions $\mathrm{C}, \mathrm{D}, \mathrm{E}$, and $\mathrm{F}$. This result demonstrates the anthropometric differences between the men and women in our study group. Anthropometric studies have shown that men are more broadshouldered than women (22). The high muscular activity for the short subjects in position B seemed to relate more to shoulder elevation than to arm support. This difference may be due to the operators' having less experience with that position, as well as to the operator's' adjustment of table height to more than $0.02 \mathrm{~m}$ above elbow height. Seven of the short subjects had adjusted the table to more than $0.02 \mathrm{~m}$ above their elbow height. We had expected therefore for position $B$ to be given higher comfort ratings among the short subjects than it received, since this position is also within the natural range of motion for the shoulder and arm. From an ergonomic point of view, position $B$ is preferable. In this position it was easy to support the arm, and for the tall subjects this ease was reflected in low activity in the trapezius muscles and low perceived exertion ratings for both the shoulder and the hand-forearm. Joint positions of the shoulder-arm were close to neutral. We believe that, through information and active training, it would be possible for many operators to learn to appreciate this position.

Whether the differences found for tall and short persons were affected by other gender-related factors than anthropometry, such as motor control, physiology and the like, is uncertain.

The analysis of the comfort ratings showed a clear preference for position $\mathrm{D}$ for the tall subjects and position $\mathrm{C}$, closely followed by position $\mathrm{D}$, for the short subjects. Perceived exertion ratings for the shoulder followed the same pattern, but, for the hand-forearm, both the tall and the short subjects preferred position D. It is probably difficult for the subjects to distinguish between comfort and perceived exertion, and therefore the results of the ratings were similar.

The tall subjects bent their neck more than the short subjects possibly because the screen was placed at a fixed height. No extremes were found in the neck flexion results (23), and the results were in accordance with findings in other studies among VDU operators $(3,5,9,18)$.

In position $C$ and $D$ the overall neck and arm postures were as close to neutral joint positions as possible when computer mouse work is performed and a keyboard is present (6).

The EMG pattern (percentage of maximal voluntary electrical activity) of the left trapezius muscle was similar to that of the right, although all the study subjects used the right hand for mouse work. This finding may be the result of an effect of contralateral muscule activity or neck flexion, as described in the literature (24). When the right arm is used, the activity increases also in the left shoulder muscle.

The EMG results showed numerically higher activity in the 4 examined muscles of the short subjects (all women) than in the tall subjects (all men, except 1). This finding could be related to lower muscle force among women and to anthropometric differences, which also influence biomechanic load moments.

\section{Limitations of the study}

The data collection in this study was made during a period of only 2 minutes in each position. The positions chosen were based on experiences from field studies $(8,17)$, which showed that long hours of work with the mouse and work with the mouse nonoptimally located on the table seem to be risk factors for upper-limb symptoms. This study focused on the location of the mouse only.

When the MacReflex system is used, short sampling periods are necessary due to time-consuming data analysis. However, all the subjects were experienced computer operators and should not have had any initial difficulties in performing the work. They were, on the other hand, not trained to work with the mouse in all the positions studied. This difference may have led to extra muscular load with unfamiliar positions of the mouse.

Muscle activity was studied from only 4 muscles. The 4 muscles were chosen because of earlier reports on musculoskeletal symptoms and muscular loads during VDU work $(20,21,24,26,27)$.

There were some problems in connection with the MacReflex system. Marker sorting problems were numerous. Even though the worktask was static, the markers changed position to a large extent, and the sorting procedure was time-consuming.

The work performed in this study was text editing, and the results cannot be generalized to other worktasks. There are many mouse types on the market today, and this study used only 1 of the standard mice (BusMouse II). The mouse 
parameters (software) were regulated for normal use with the same mean velocity for all the subjects.

\section{Concluding remarks}

- The VDU operators in this study preferred a table position for the mouse which was close to the relaxed, neutral posture of the arm combined with arm support (position D for the tall subjects and position C-D for the short ones, in accordance with differences in anthropometry).

- The tall and broad-shouldered subjects worked with larger inward rotation of the shoulder in a mouse position immediately in front of them than short and narrow-shouldered subjects did.

- Short and narrow-shouldered subjects worked in a more strenuous position than the tall and broad-shouldered subjects did, with larger outward rotation and abduction of the shoulder in a mouse position lateral to the keyboard.

- Arm support markedly reduced muscle load in the neckshoulder region among the VDU operators.

\section{References}

1. Bureau of Labour Statistics. Bureau of Labour Statistics report on survey of occupational injuries and illnesses. Washington (DC): Bureal of Labour Statistics, US Department of Labor, 1992.

2. Hagberg M, Wegman DH. Prevalence rates and odds ratios of shoulder-neck diseases in different occupational groups. $\mathrm{Br} J$ Ind Med 1987;44:602-10.

3. Sauter S, Schleifer L, Knutson S. Work posture, workstation design, and musculoskeletal discomfort in a VDT data entry task. Hum Factors 1991;33:151- 67 .

4. Bergqvist U. Health problems during work with visual display terminals. Stockholm: Arbetarskyddsverket, 1993:1 - 59. Arbete och hälsa 28 .

5. Bergqvist U, Wolgast E, Nilsson B, Voss M. Musculoskeletal disorders among visual display terminal workers - individual, ergonomic and work organizational factors. Ergonomics 1995;38(4): $763-76$.

6. Karlqvist L, Hagberg M, Selin K. Variation in upper limb posture and movement during word processing with and without mouse use. Ergonomics 1994:37(7):1261-7.

7. Franzblau A, Flaschner D, Albers J, Blitz S, Werner R, Armstrong T. Medical screen of office workers for upper extremity cumulative trauma disorders. Arch Environ Health 1993;48(3):164-70.

8. Karlqvist L, Hagberg M, Köster M, Wenemark M, Ånell R. Musculoskeletal symptoms among computer-assisted design (CAD) operators and evaluation of a self-assessment questionnaire. Int J Occup Environ Health 1996;2:185-94.

9. Grandjean E. Fitting the task to the man: an ergonomics approach. 4th edition. London: Taylor \& Francis, 1988;5.5:68 -9

10. Schüldt K, Ekholm J, Harms-Ringdahl K, Németh G, Arborelius U Effects of arm support or suspension on neck and shoulder muscle activity during sedentary work. Scand J Rehabil Med 1987;19:77_ 87.

11. Greene WB, Heckman JD, editors. The clinical measurement of joint motion. Rosemont (IL): American Academy of Orthopedic Surgeons, 1994.

12. Delagi EF, Perotti A, Ianzzetti J, Morrison D. In: Anatomic guide for the electromyographer - the limbs. Springfield (IL): Charles C Thomas Publisher, 1981.

13. Jensen C, Vasseljen O, Westgaard R. The influence of electrode position on bipolar surface electromyogram recordings of the upper trapezius muscle. Eur J Appl Physiol 1993;67:266-73.

14. Mathiassen SE, Winkel J, Hägg G. Normalization of surface EMG amplitude from the upper trapezius muscle in ergonomic studies a review. J Electromyographical Kinesiology 1995;5:197-226.

15. Gardner M, Altman D. Statistics with confidence, BMJ 1989.

16. Karlqvist L, Hagberg M, Hansson G-Ä, Waldenström M. Good working environments for graphics industry VDU operators using a mouse. Montreal: PREMUS, 1995.

17. Arnetz B, Waldenström M, Karlqvist L, Thernsjö M. Bench-marking for enhanced work environment, skills utilization and efficiency. Stockholm: Ericsson company report, 1995.

18. Hünting W, Läubli T, Grandjean E. Postural and visual loads at VDT workplaces. Ergonomics 1981;24:917-31.

19. Hagberg M, Sundelin G. Discomfort and load on the upper trapezius muscle when operating a wordprocessor. Ergonomics 1986; 29(12):1637-45.

20. Harms-Ringdahl K. On assessment of shoulder exercise and loadelicited pain in the cervical spine. Scand J Rehabil Med 1986;14:1-40.

21. Sundelin G, Hagberg M. Effects of exposurc to excessive drafts on myoelectric activity in shoulder muscles. J Electromyographical Kinesiology 1992;2:36-41.

22. Pheasant S. Bodyspace: anthropometry, ergonomics and design. London: Taylor \& Francis, 1986:67-120.

23. Harms-Ringdahl K, Ekholm J. Intensity and character of pain and muscular activity levels elicited by maintained extreme flexion position of the lower-cervical-upper-thoracic spine. Scand J Rehabil Med 1986;18:117-26.

24. Schïldt K, Harms-Ringdahl K. Activity levels during isometric test contractions of neck and shoulder muscles. Scand J Rehabil Med 1988;20:117-27.

25. Karlqvist L, Hagberg M, Hansson G- $\AA$, Selin K. Arbetsbord för bildskärmsarbete med datormus - ntveckling och utvärdering [Work tables for VDU work when using a mouse - development and evaluation]. Stockholm: Arbetarskyddsverket, 1996:1-30. Arbete och Hälsa 8. In Swedish.

26. Armstrong TJ, Martin BJ, Franzblau A, Rempel DM, Johnson PW. Mouse input devices and work-related upper limb disorders. In Grieco A, Molteni G, Occhipinti E, Piccoli B, editors. Work with display units 94. Amsterdam: Elsevier Science BV, 1995:375 — 80.

27. Fernström E, Ericson M. Computer mouse or track-point - - effects on muscular load and operator experience. Appl Ergon. In press. 
Computer mouse position

\section{Appendix}

Table 1. Mean joint positions during work with the mouse in 6 different positions $(A-F)-$ measured in degrees.

\begin{tabular}{|c|c|c|c|c|c|c|c|c|c|c|c|c|c|}
\hline & \multirow[t]{3}{*}{$N$} & \multicolumn{12}{|c|}{ Mouse position ${ }^{\mathrm{a}}$} \\
\hline & & \multicolumn{2}{|c|}{ A } & \multicolumn{2}{|c|}{$\mathrm{B}$} & \multicolumn{2}{|c|}{$\mathrm{C}$} & \multicolumn{2}{|r|}{ D } & \multicolumn{2}{|c|}{$E$} & \multicolumn{2}{|r|}{$\mathrm{F}$} \\
\hline & & Mean & SD & Mean & SD & Mean & $\mathrm{SD}$ & Mean & SD & Mean & $S D$ & Mean & SD \\
\hline \multicolumn{14}{|c|}{ Neck flexion } \\
\hline $\begin{array}{l}\text { Men } \\
\text { Women }\end{array}$ & $\begin{array}{r}8 \\
10\end{array}$ & $\begin{array}{l}27 \\
21\end{array}$ & $\begin{array}{l}7.3 \\
6.5\end{array}$ & $\begin{array}{l}29 \\
19\end{array}$ & $\begin{array}{l}8.7 \\
8.8\end{array}$ & $\begin{array}{l}27 \\
22\end{array}$ & $\begin{array}{l}6.2 \\
7.6\end{array}$ & $\begin{array}{l}28 \\
24\end{array}$ & $\begin{array}{l}7.2 \\
5.8\end{array}$ & $\begin{array}{l}29 \\
25\end{array}$ & $\begin{array}{l}4.3 \\
5.3\end{array}$ & $\begin{array}{l}29 \\
24\end{array}$ & $\begin{array}{l}6.7 \\
5.8\end{array}$ \\
\hline \multicolumn{14}{|c|}{ Shoulder rotation } \\
\hline $\begin{array}{l}\text { Men } \\
\text { Women }\end{array}$ & $\begin{array}{r}8 \\
10\end{array}$ & $\begin{array}{l}-42^{*} \\
-29^{\star}\end{array}$ & $\begin{array}{l}12.3 \\
11.6\end{array}$ & $\begin{array}{l}-29 \\
-24\end{array}$ & $\begin{array}{l}8.6 \\
9.0\end{array}$ & $\begin{array}{l}16^{*} \\
27^{*}\end{array}$ & $\begin{array}{r}8.1 \\
10.5\end{array}$ & $\begin{array}{l}17 \\
22\end{array}$ & $\begin{array}{l}6.3 \\
5.9\end{array}$ & $\begin{array}{l}40^{*} \\
51^{*}\end{array}$ & $\begin{array}{l}7.3 \\
9.3\end{array}$ & $\begin{array}{l}36 \\
40\end{array}$ & $\begin{array}{l}6.4 \\
5.4\end{array}$ \\
\hline \multicolumn{14}{|c|}{ Shoulder abduction } \\
\hline $\begin{array}{l}\text { Men } \\
\text { Women }\end{array}$ & $\begin{array}{r}8 \\
10\end{array}$ & $\begin{array}{l}19 \\
18\end{array}$ & $\begin{array}{r}10.4 \\
6.6\end{array}$ & $\begin{array}{l}16 \\
18\end{array}$ & $\begin{array}{r}10.9 \\
7.7\end{array}$ & $\begin{array}{l}24 \\
19\end{array}$ & $\begin{array}{l}8.8 \\
4.2\end{array}$ & $\begin{array}{l}21 \\
32\end{array}$ & $\begin{array}{r}7.4 \\
11.6\end{array}$ & $\begin{array}{l}33 \\
35\end{array}$ & $\begin{array}{r}15.2 \\
7.5\end{array}$ & $\begin{array}{l}31 \\
37\end{array}$ & $\begin{array}{r}13.4 \\
6.6\end{array}$ \\
\hline \multicolumn{14}{|c|}{ Shoulder flexion } \\
\hline $\begin{array}{l}\text { Men } \\
\text { Women }\end{array}$ & $\begin{array}{r}8 \\
10\end{array}$ & $\begin{array}{r}2 \\
-6\end{array}$ & $\begin{array}{l}10.3 \\
10.4\end{array}$ & $\begin{array}{l}19 \\
15\end{array}$ & $\begin{array}{l}11.0 \\
14.8\end{array}$ & $\begin{array}{r}0 \\
-10\end{array}$ & $\begin{array}{l}11.0 \\
13.5\end{array}$ & $\begin{array}{l}10 \\
12\end{array}$ & $\begin{array}{r}6.8 \\
11.2\end{array}$ & $\begin{array}{r}7 \\
-4\end{array}$ & $\begin{array}{r}8.5 \\
11.3\end{array}$ & $\begin{array}{l}13 \\
14\end{array}$ & $\begin{array}{r}14.1 \\
9.0\end{array}$ \\
\hline \multicolumn{14}{|c|}{ Wrist extension } \\
\hline $\begin{array}{l}\text { Men } \\
\text { Women }\end{array}$ & $\begin{array}{r}8 \\
10\end{array}$ & $\begin{array}{l}23 \\
22\end{array}$ & $\begin{array}{l}5.3 \\
5.4\end{array}$ & $\begin{array}{l}17 \\
19\end{array}$ & $\begin{array}{l}4.6 \\
5.0\end{array}$ & $\begin{array}{l}32 \\
26\end{array}$ & $\begin{array}{l}12.2 \\
14.0\end{array}$ & $\begin{array}{l}23 \\
23\end{array}$ & $\begin{array}{l}6.5 \\
3.4\end{array}$ & $\begin{array}{l}41 \\
27\end{array}$ & $\begin{array}{r}13.6 \\
7.0\end{array}$ & $\begin{array}{l}24 \\
27\end{array}$ & $\begin{array}{r}7.1 \\
12.0\end{array}$ \\
\hline \multicolumn{14}{|c|}{ Wrist deviation } \\
\hline $\begin{array}{l}\text { Men } \\
\text { Women }\end{array}$ & $\begin{array}{r}8 \\
10\end{array}$ & $\begin{array}{r}11 \\
9\end{array}$ & $\begin{array}{l}9.6 \\
8.6\end{array}$ & $\begin{array}{l}10 \\
11\end{array}$ & $\begin{array}{l}5.5 \\
5.7\end{array}$ & $\begin{array}{r}13 \\
9\end{array}$ & $\begin{array}{r}10.0 \\
9.5\end{array}$ & $\begin{array}{l}11 \\
10\end{array}$ & $\begin{array}{l}3.8 \\
6.2\end{array}$ & $\begin{array}{r}14 \\
6\end{array}$ & $\begin{array}{l}8.9 \\
5.7\end{array}$ & $\begin{array}{l}6 \\
8\end{array}$ & $\begin{array}{r}10.4 \\
6.9\end{array}$ \\
\hline \multicolumn{14}{|c|}{ Elbow flexion } \\
\hline $\begin{array}{l}\text { Men } \\
\text { Women }\end{array}$ & $\begin{array}{r}8 \\
10\end{array}$ & $\begin{array}{l}76 \\
69\end{array}$ & $\begin{array}{r}10.2 \\
4.2\end{array}$ & $\begin{array}{l}95 \\
91\end{array}$ & $\begin{array}{l}15.9 \\
12.0\end{array}$ & $\begin{array}{l}98 \\
84\end{array}$ & $\begin{array}{r}13.1 \\
7.1\end{array}$ & $\begin{array}{l}100 \\
106\end{array}$ & $\begin{array}{r}11.6 \\
5.2\end{array}$ & $\begin{array}{l}110 \\
113\end{array}$ & $\begin{array}{l}24.0 \\
13.2\end{array}$ & $\begin{array}{l}115 \\
117\end{array}$ & $\begin{array}{r}17.9 \\
9.6\end{array}$ \\
\hline \multicolumn{14}{|c|}{$\begin{array}{l}\text { Shoulder elevation (mm) } \\
\text { as difference between } \\
\text { reference value and } \\
\text { positions }\end{array}$} \\
\hline $\begin{array}{l}\text { Men } \\
\text { Women }\end{array}$ & $\begin{array}{r}8 \\
10\end{array}$ & $\begin{array}{r}-15 \\
-3\end{array}$ & $\begin{array}{l}26.2 \\
12.8\end{array}$ & $\begin{array}{r}-17^{*} \\
8^{*}\end{array}$ & $\begin{array}{r}9.9 \\
16.7\end{array}$ & $\begin{array}{r}-10 \\
-7\end{array}$ & $\begin{array}{l}18.3 \\
10.5\end{array}$ & $\begin{array}{l}-20 \\
-16\end{array}$ & $\begin{array}{l}20.4 \\
12.4\end{array}$ & $\begin{array}{r}-11 \\
-7\end{array}$ & $\begin{array}{r}15.2 \\
9.1\end{array}$ & $\begin{array}{l}-30 \\
-33\end{array}$ & $\begin{array}{l}17.1 \\
16.2\end{array}$ \\
\hline
\end{tabular}

a See figure 1.

* $\mathrm{P}<0.05$, difference between the men and women. 
Table 2. Mean joint position during work with the mouse in six different positions (A-F) - measured in degrees.

\begin{tabular}{|c|c|c|c|c|c|c|c|c|c|c|c|c|c|}
\hline & \multirow[t]{3}{*}{$N$} & \multicolumn{12}{|c|}{ Mouse position ${ }^{a}$} \\
\hline & & \multicolumn{2}{|c|}{ A } & \multicolumn{2}{|c|}{$B$} & \multicolumn{2}{|c|}{ C } & \multicolumn{2}{|c|}{$D$} & \multicolumn{2}{|r|}{$E$} & \multicolumn{2}{|r|}{$\mathrm{F}$} \\
\hline & & Mean & SD & Mean & SD & Mean & SD & Mean & $S D$ & Mean & SD & Mean & SD \\
\hline \multicolumn{14}{|l|}{ Neck flexion } \\
\hline $\begin{array}{l}\text { Broad shoulders } \\
\text { Narrow shoulders }\end{array}$ & $\begin{array}{l}9 \\
9\end{array}$ & $\begin{array}{l}27 \\
20\end{array}$ & $\begin{array}{l}6.8 \\
6.6\end{array}$ & $\begin{array}{l}30 \\
19\end{array}$ & $\begin{array}{l}8.1 \\
8.8\end{array}$ & $\begin{array}{l}28 \\
22\end{array}$ & $\begin{array}{l}6.6 \\
7.6\end{array}$ & $\begin{array}{l}28 \\
24\end{array}$ & $\begin{array}{l}6.6 \\
5.8\end{array}$ & $\begin{array}{l}30 \\
25\end{array}$ & $\begin{array}{l}4.1 \\
5.3\end{array}$ & $\begin{array}{l}29 \\
24\end{array}$ & $\begin{array}{l}6.0 \\
5.8\end{array}$ \\
\hline \multicolumn{14}{|l|}{ Shoulder rotation } \\
\hline $\begin{array}{l}\text { Broad shoulders } \\
\text { Narrow shoulders }\end{array}$ & $\begin{array}{l}9 \\
9\end{array}$ & $\begin{array}{l}-41^{*} \\
-27^{*}\end{array}$ & $\begin{array}{l}11.7 \\
11.4\end{array}$ & $\begin{array}{l}-28 \\
-25\end{array}$ & $\begin{array}{r}6.7 \\
10.8\end{array}$ & $\begin{array}{l}16^{*} \\
28^{*}\end{array}$ & $\begin{array}{r}7.3 \\
10.7\end{array}$ & $\begin{array}{l}17 \\
22\end{array}$ & $\begin{array}{l}6.4 \\
6.0\end{array}$ & $\begin{array}{l}41^{*} \\
52^{*}\end{array}$ & $\begin{array}{l}8.0 \\
9.4\end{array}$ & $\begin{array}{l}35^{*} \\
41^{*}\end{array}$ & $\begin{array}{l}4.7 \\
5.5\end{array}$ \\
\hline \multicolumn{14}{|l|}{ Shoulder abduction } \\
\hline $\begin{array}{l}\text { Broad shoulders } \\
\text { Narrow shoulders }\end{array}$ & $\begin{array}{l}9 \\
9\end{array}$ & $\begin{array}{l}21 \\
15\end{array}$ & $\begin{array}{l}9.0 \\
6.7\end{array}$ & $\begin{array}{l}15 \\
19\end{array}$ & $\begin{array}{r}10.2 \\
7.5\end{array}$ & $\begin{array}{l}20 \\
22\end{array}$ & $\begin{array}{l}7.7 \\
6.1\end{array}$ & $\begin{array}{l}21 \\
32\end{array}$ & $\begin{array}{r}7.1^{*} \\
12.4^{*}\end{array}$ & $\begin{array}{l}33 \\
35\end{array}$ & $\begin{array}{r}14.4 \\
7.6\end{array}$ & $\begin{array}{l}30 \\
39\end{array}$ & $\begin{array}{r}12.3 \\
6.4\end{array}$ \\
\hline \multicolumn{14}{|l|}{ Shoulder flexion } \\
\hline $\begin{array}{l}\text { Broad shoulders } \\
\text { Narrow shoulders }\end{array}$ & $\begin{array}{l}9 \\
9\end{array}$ & $\begin{array}{l}3^{*} \\
8^{*}\end{array}$ & $\begin{array}{r}10.0 \\
9.4\end{array}$ & $\begin{array}{l}18 \\
15\end{array}$ & $\begin{array}{l}12.4 \\
14.3\end{array}$ & $\begin{array}{r}-2 \\
-10\end{array}$ & $\begin{array}{l}11.2 \\
14.2\end{array}$ & $\begin{array}{l}11 \\
10\end{array}$ & $\begin{array}{r}7.9 \\
11.2\end{array}$ & $\begin{array}{r}6 \\
-4\end{array}$ & $\begin{array}{r}8.4 \\
11.9\end{array}$ & $\begin{array}{l}13 \\
14\end{array}$ & $\begin{array}{r}13.7 \\
8.8\end{array}$ \\
\hline \multicolumn{14}{|l|}{ Wrist extension } \\
\hline $\begin{array}{l}\text { Broad shoulders } \\
\text { Narrow shoulders }\end{array}$ & $\begin{array}{l}9 \\
9\end{array}$ & $\begin{array}{l}22 \\
23\end{array}$ & $\begin{array}{l}4.5 \\
6.1\end{array}$ & $\begin{array}{l}17 \\
19\end{array}$ & $\begin{array}{l}4.4 \\
5.4\end{array}$ & $\begin{array}{l}31 \\
26\end{array}$ & $\begin{array}{l}11.0 \\
15.1\end{array}$ & $\begin{array}{l}23 \\
23\end{array}$ & $\begin{array}{l}6.1 \\
4.2\end{array}$ & $\begin{array}{l}40 \\
28\end{array}$ & $\begin{array}{r}13.8 \\
7.4\end{array}$ & $\begin{array}{l}23 \\
29\end{array}$ & $\begin{array}{r}5.8 \\
12.5\end{array}$ \\
\hline \multicolumn{14}{|l|}{ Wrist deviation } \\
\hline $\begin{array}{l}\text { Broad shoulders } \\
\text { Narrow shoulders }\end{array}$ & $\begin{array}{l}9 \\
9\end{array}$ & $\begin{array}{r}9 \\
11\end{array}$ & $\begin{array}{r}7.0 \\
11.0\end{array}$ & $\begin{array}{l}10 \\
11\end{array}$ & $\begin{array}{l}4.4 \\
6.5\end{array}$ & $\begin{array}{r}15 \\
7\end{array}$ & $\begin{array}{r}5.9 \\
11.2\end{array}$ & $\begin{array}{l}11 \\
10\end{array}$ & $\begin{array}{l}3.6 \\
6.6\end{array}$ & $\begin{array}{r}13 \\
5\end{array}$ & $\begin{array}{l}8.7 \\
5.4\end{array}$ & $\begin{array}{l}6 \\
7\end{array}$ & $\begin{array}{r}10.0 \\
7.1\end{array}$ \\
\hline \multicolumn{14}{|l|}{ Elbow flexion } \\
\hline $\begin{array}{l}\text { Broad shoulders } \\
\text { Narrow shoulders }\end{array}$ & $\begin{array}{l}9 \\
9\end{array}$ & $\begin{array}{l}77 \\
67\end{array}$ & $\begin{array}{l}8.6 \\
3.5\end{array}$ & $\begin{array}{l}96 \\
89\end{array}$ & $\begin{array}{r}14.5 \\
12.5\end{array}$ & $\begin{array}{l}95 \\
84\end{array}$ & $\begin{array}{r}13.8 \\
7.2\end{array}$ & $\begin{array}{l}102 \\
104\end{array}$ & $\begin{array}{r}10.7 \\
7.2\end{array}$ & $\begin{array}{l}111 \\
112\end{array}$ & $\begin{array}{l}23.3 \\
12.7\end{array}$ & $\begin{array}{l}114 \\
118\end{array}$ & $\begin{array}{l}16.4 \\
10.5\end{array}$ \\
\hline \multicolumn{14}{|c|}{$\begin{array}{l}\text { Shoulder elevation (mm) } \\
\text { as difference between } \\
\text { reference value } \\
\text { and positions }\end{array}$} \\
\hline $\begin{array}{l}\text { Broad shoulders } \\
\text { Narrow shoulders }\end{array}$ & $\begin{array}{l}9 \\
9\end{array}$ & $\begin{array}{r}-10 \\
-6\end{array}$ & $\begin{array}{l}23.8 \\
17.5\end{array}$ & $\begin{array}{r}-11 \\
5\end{array}$ & $\begin{array}{l}13.8 \\
19.9\end{array}$ & $\begin{array}{r}-3 \\
-14\end{array}$ & $\begin{array}{l}11.7 \\
14.8\end{array}$ & $\begin{array}{l}-19 \\
-17\end{array}$ & $\begin{array}{l}20.2 \\
11.6\end{array}$ & $\begin{array}{r}-7 \\
-11\end{array}$ & $\begin{array}{r}14.5 \\
9.2\end{array}$ & $\begin{array}{l}-32 \\
-31\end{array}$ & $\begin{array}{l}19.8 \\
12.9\end{array}$ \\
\hline
\end{tabular}

a See figure 1 .

* $P<0.05$, difference between broad and narrow shouldered subjects. 
Table 3. Analysis of variance for repeated measurements of the joint positions in the neck and arm and the mouse positions. Interactions between the mouse positions and gender, height or shoulder breadth. Two-way analysis of variance for repeated measurements with degrees (or millimeters) as the dependent variable. ( $\mathrm{df}=$ degrees of freedom)

\begin{tabular}{|c|c|c|c|}
\hline Source & $d f$ & F-Value & P-Value \\
\hline \multicolumn{4}{|l|}{ Neck flexion } \\
\hline $\begin{array}{l}\text { Gender/height/shoulder breadth } \\
\text { Positions } \\
\text { Positions · gender/height/shoulder breadth }\end{array}$ & $\begin{array}{l}1 \\
5 \\
5\end{array}$ & $\begin{array}{l}3.199 / 1.908 / 6.424 \\
2.563 / 3.007 / 3.317 \\
1.803 / 1.777 / 2.928\end{array}$ & $\begin{array}{l}0.0939 / 0.1874 / 0.0229 \\
0.0339 / 0.0158 / 0.0092 \\
0.1223 / 0.1278 / 0.0181\end{array}$ \\
\hline \multicolumn{4}{|l|}{ Shoulder rotation } \\
\hline $\begin{array}{l}\text { Gender/height/shoulder breadth } \\
\text { Positions } \\
\text { Positions - gender/height/shoulder breadth }\end{array}$ & $\begin{array}{l}1 \\
5 \\
5\end{array}$ & $\begin{array}{l}8.170 / 7.959 / 8.800 \\
386.893 / 386.642 / 396.926 \\
1.154 / 1.198 / 1.605\end{array}$ & $\begin{array}{l}0.0120 / 0.0129 / 0.0096 \\
0.0001 / 0.0001 / 0.0001 \\
0.3400 / 0.3183 / 0.1619\end{array}$ \\
\hline \multicolumn{4}{|l|}{ Shoulder abduction } \\
\hline $\begin{array}{l}\text { Gender/height/shoulder breadth } \\
\text { Positions } \\
\text { Positions - gender/height/shoulder breadth }\end{array}$ & $\begin{array}{l}1 \\
5 \\
5\end{array}$ & $\begin{array}{l}0.659 / 1.065 / 1.288 \\
17.213 / 17.667 / 18.138 \\
2.401 / 2.372 / 2.619\end{array}$ & $\begin{array}{l}0.4296 / 0.3184 / 0.2742 \\
0.0001 / 0.0001 / 0.0001 \\
0.0448 / 0.0471 / 0.0308\end{array}$ \\
\hline \multicolumn{4}{|l|}{ Shoulder flexion } \\
\hline $\begin{array}{l}\text { Gender/height/shoulder breadth } \\
\text { Positions } \\
\text { Positions · gender/height/shoulder breadth }\end{array}$ & $\begin{array}{l}1 \\
5 \\
5\end{array}$ & $\begin{array}{l}2.055 / 1.618 / 2.347 \\
23.590 / 23.950 / 23.969 \\
2.251 / 1.701 / 1.626\end{array}$ & $\begin{array}{l}0.1723 / 0.2228 / 0.1463 \\
0.0001 / 0.0001 / 0.0001 \\
0.0578 / 0.1448 / 0.1635\end{array}$ \\
\hline \multicolumn{4}{|l|}{ Shoulder elevation } \\
\hline $\begin{array}{l}\text { Gender/height/shoulder breadth } \\
\text { Positions } \\
\text { Positions - gender/height/shoulder breadth }\end{array}$ & $\begin{array}{l}1 \\
5 \\
5\end{array}$ & $\begin{array}{l}3.291 / 3.309 / 0.240 \\
9.346 / 10.713 / 9.755 \\
2.233 / 3.060 / 2.162\end{array}$ & $\begin{array}{l}0.0897 / 0.0889 / 0.6316 \\
0.0001 / 0.0001 / 0.0001 \\
0.0596 / 0.0144 / 0.0673\end{array}$ \\
\hline \multicolumn{4}{|l|}{ Elbow flexion } \\
\hline $\begin{array}{l}\text { Gender/height/shoulder breadth } \\
\text { Positions } \\
\text { Positions - gender/height/shoulder breadth }\end{array}$ & $\begin{array}{l}1 \\
5 \\
5\end{array}$ & $\begin{array}{l}0.663 / 1.051 / 1.095 \\
36.362 / 35.412 / 36.998 \\
1.892 / 0.984 / 1.517\end{array}$ & $\begin{array}{l}0.4282 / 0.3215 / 0.3120 \\
0.0001 / 0.0001 / 0.0001 \\
0.1058 / 0.4332 / 0.1948\end{array}$ \\
\hline \multicolumn{4}{|l|}{ Wrist extension } \\
\hline $\begin{array}{l}\text { Gender/height/shoulder breadth } \\
\text { Positions } \\
\text { Positions · gender/height/shoulder breadth }\end{array}$ & $\begin{array}{l}1 \\
5 \\
5\end{array}$ & $\begin{array}{l}1.505 / 1.744 / 0.135 \\
7.204 / 6.452 / 6.550 \\
2.098 / 2.000 / 2.234\end{array}$ & $\begin{array}{l}0.2388 / 0.2064 / 0.7180 \\
0.0001 / 0.0001 / 0.0001 \\
0.0750 / 0.0883 / 0.0596\end{array}$ \\
\hline \multicolumn{4}{|l|}{ Wrist deviation } \\
\hline $\begin{array}{l}\text { Height/shoulder breadth } \\
\text { Positions } \\
\text { Positions - height/shoulder breadth }\end{array}$ & $\begin{array}{l}1 \\
5 \\
5\end{array}$ & $\begin{array}{l}0.064 / 0.401 \\
0.649 / 0.661 \\
0.695 / 1.782\end{array}$ & $\begin{array}{l}0.8043 / 0.5359 \\
0.6628 / 0.6538 \\
0.6288 / 0.1269\end{array}$ \\
\hline
\end{tabular}

Table 4. Mean muscular activity (percentage of maximal voluntary electrical activity) during work with the mouse in 6 different positions $(A-F)$.

\begin{tabular}{|c|c|c|c|c|c|c|c|c|c|c|c|c|c|}
\hline \multirow[t]{3}{*}{ Muscle } & \multirow[t]{3}{*}{$N$} & \multicolumn{12}{|c|}{ Mouse position ${ }^{\mathrm{a}}$} \\
\hline & & \multicolumn{2}{|c|}{ A } & \multicolumn{2}{|c|}{ B } & \multicolumn{2}{|c|}{ c } & \multicolumn{2}{|c|}{ D } & \multicolumn{2}{|c|}{$\mathrm{E}$} & \multicolumn{2}{|c|}{ F } \\
\hline & & Mean & $\mathrm{SD}$ & Mean & SD & Mean & SD & Mean & SD & Mean & SD & Mean & SD \\
\hline \multicolumn{14}{|c|}{ Left trapezius } \\
\hline $\begin{array}{l}\text { Men } \\
\text { Women }\end{array}$ & $\begin{array}{r}8 \\
10\end{array}$ & $\begin{array}{l}4.0 \\
6.4\end{array}$ & $\begin{array}{l}3.7 \\
5.4\end{array}$ & $\begin{array}{l}3.3 \\
7.5\end{array}$ & $\begin{array}{l}2.9 \\
9.1\end{array}$ & $\begin{array}{l}4.8 \\
6.0\end{array}$ & $\begin{array}{l}3.8 \\
4.4\end{array}$ & $\begin{array}{l}3.9 \\
4.2\end{array}$ & $\begin{array}{l}3.7 \\
3.3\end{array}$ & $\begin{array}{l}4.4 \\
8.5\end{array}$ & $\begin{array}{l}3.5 \\
8.2\end{array}$ & $\begin{array}{l}3.4 \\
5.0\end{array}$ & $\begin{array}{l}2.6 \\
2.1\end{array}$ \\
\hline \multicolumn{14}{|c|}{ Right trapezius } \\
\hline $\begin{array}{l}\text { Men } \\
\text { Women }\end{array}$ & $\begin{array}{r}8 \\
10\end{array}$ & $\begin{array}{l}2.7 \\
7.5\end{array}$ & $\begin{array}{l}2.8 \\
7.3\end{array}$ & $\begin{array}{r}2.4 \\
10.4\end{array}$ & $\begin{array}{r}2.4 \\
12.1\end{array}$ & $\begin{array}{l}3.4 \\
6.3\end{array}$ & $\begin{array}{l}2.6 \\
6.0\end{array}$ & $\begin{array}{l}1.9 \\
4.3\end{array}$ & $\begin{array}{l}1.9 \\
3.6\end{array}$ & $\begin{array}{l}3.3 \\
7.2\end{array}$ & $\begin{array}{l}1.9 \\
7.6\end{array}$ & $\begin{array}{l}1.0^{*} \\
4.2^{*}\end{array}$ & $\begin{array}{l}0.9 \\
3.9\end{array}$ \\
\hline \multicolumn{14}{|c|}{ Right deltoid } \\
\hline $\begin{array}{l}\text { Men } \\
\text { Women }\end{array}$ & $\begin{array}{r}8 \\
10\end{array}$ & $\begin{array}{l}1.0 \\
2.2\end{array}$ & $\begin{array}{l}0.7 \\
2.5\end{array}$ & $\begin{array}{l}2.1 \\
4.5\end{array}$ & $\begin{array}{l}3.3 \\
5.6\end{array}$ & $\begin{array}{l}1.5 \\
3.5\end{array}$ & $\begin{array}{l}1.5 \\
3.5\end{array}$ & $\begin{array}{l}1.0 \\
5.9\end{array}$ & $\begin{array}{l}0.8 \\
3.5\end{array}$ & $\begin{array}{l}1.6^{*} \\
5.7^{*}\end{array}$ & $\begin{array}{l}1.3 \\
5.4\end{array}$ & $\begin{array}{l}1.1^{*} \\
4.5^{*}\end{array}$ & $\begin{array}{l}0.5 \\
3.8\end{array}$ \\
\hline \multicolumn{14}{|c|}{ Right extensor digitorum } \\
\hline $\begin{array}{l}\text { Men } \\
\text { Women }\end{array}$ & $\begin{array}{r}8 \\
10\end{array}$ & $\begin{array}{l}6.8 \\
8.5\end{array}$ & $\begin{array}{l}3.8 \\
1.6\end{array}$ & $\begin{array}{l}5.9^{*} \\
9.4^{*}\end{array}$ & $\begin{array}{l}2.4 \\
1.8\end{array}$ & $\begin{array}{l}6.1 \\
7.7\end{array}$ & $\begin{array}{l}4.2 \\
2.2\end{array}$ & $\begin{array}{l}6.1 \\
8.4\end{array}$ & $\begin{array}{l}2.0 \\
2.1\end{array}$ & $\begin{array}{l}6.6^{*} \\
8.6^{*}\end{array}$ & $\begin{array}{l}3.4 \\
1.8\end{array}$ & $\begin{array}{l}6.7 \\
7.2\end{array}$ & $\begin{array}{l}2.6 \\
2.2\end{array}$ \\
\hline
\end{tabular}

a See figure 1.

${ }^{*} P<0.05$, difference between the men and women. 
Table 5. Mean muscular activity (percentage of maximal voluntary electrical activity) during work with the mouse in 6 different positions $(A-F)$.

\begin{tabular}{|c|c|c|c|c|c|c|c|c|c|c|c|c|c|}
\hline \multirow[t]{3}{*}{ Muscle } & \multirow[t]{3}{*}{ N } & \multicolumn{12}{|c|}{ Mouse position ${ }^{2}$} \\
\hline & & \multicolumn{2}{|c|}{ A } & \multicolumn{2}{|c|}{$B$} & \multicolumn{2}{|c|}{ C } & \multicolumn{2}{|c|}{ D } & \multicolumn{2}{|c|}{$E$} & \multicolumn{2}{|c|}{ F } \\
\hline & & Mean & SD & Mean & SD & Mean & $\mathrm{SD}$ & Mean & $\mathrm{SD}$ & Mean & $\mathrm{SD}$ & Mean & $\mathrm{SD}$ \\
\hline \multicolumn{14}{|l|}{ Left trapezius } \\
\hline $\begin{array}{l}\text { Broad shoulders } \\
\text { Narrow shoulders }\end{array}$ & $\begin{array}{l}9 \\
9\end{array}$ & $\begin{array}{l}3.8 \\
6.8\end{array}$ & $\begin{array}{l}3.6 \\
5.4\end{array}$ & $\begin{array}{l}3.6 \\
7.5\end{array}$ & $\begin{array}{l}2.7 \\
9.7\end{array}$ & $\begin{array}{l}4.5 \\
6.5\end{array}$ & $\begin{array}{l}3.6 \\
4.4\end{array}$ & $\begin{array}{l}3.9 \\
4.3\end{array}$ & $\begin{array}{l}3.4 \\
3.5\end{array}$ & $\begin{array}{l}4.6 \\
8.8\end{array}$ & $\begin{array}{l}3.3 \\
8.7\end{array}$ & $\begin{array}{l}3.7 \\
4.8\end{array}$ & $\begin{array}{l}2.2 \\
2.6\end{array}$ \\
\hline \multicolumn{14}{|l|}{ Right trapezius } \\
\hline $\begin{array}{l}\text { Broad shoulders } \\
\text { Narrow shoulders }\end{array}$ & $\begin{array}{l}9 \\
9\end{array}$ & $\begin{array}{l}3.0 \\
7.7\end{array}$ & $\begin{array}{l}2.7 \\
7.6\end{array}$ & $\begin{array}{r}3.1 \\
10.5\end{array}$ & $\begin{array}{r}2.7 \\
12.9\end{array}$ & $\begin{array}{l}3.5 \\
6.5\end{array}$ & $\begin{array}{l}2.3 \\
6.5\end{array}$ & $\begin{array}{l}2.4 \\
4.1\end{array}$ & $\begin{array}{l}1.9 \\
4.0\end{array}$ & $\begin{array}{l}3.9 \\
7.0\end{array}$ & $\begin{array}{l}1.9 \\
8.2\end{array}$ & $\begin{array}{l}1.3 \\
4.3\end{array}$ & $\begin{array}{l}1.1 \\
4.1\end{array}$ \\
\hline \multicolumn{14}{|l|}{ Right deltoid } \\
\hline $\begin{array}{l}\text { Broad shoulders } \\
\text { Narrow shoulders }\end{array}$ & $\begin{array}{l}9 \\
9\end{array}$ & $\begin{array}{l}1.0 \\
2.4\end{array}$ & $\begin{array}{l}0.7 \\
2.6\end{array}$ & $\begin{array}{l}1.2 \\
4.9\end{array}$ & $\begin{array}{l}3.1 \\
5.8\end{array}$ & $\begin{array}{l}1.4 \\
3.8\end{array}$ & $\begin{array}{l}1.4 \\
3.6\end{array}$ & $\begin{array}{l}2.5 \\
4.9\end{array}$ & $\begin{array}{l}3.3 \\
3.7\end{array}$ & $\begin{array}{l}2.0 \\
5.8\end{array}$ & $\begin{array}{l}1.3 \\
5.8\end{array}$ & $\begin{array}{l}1.3^{*} \\
4.7^{*}\end{array}$ & $\begin{array}{l}0.9 \\
3.8\end{array}$ \\
\hline \multicolumn{14}{|c|}{ Right extensor digitorum } \\
\hline $\begin{array}{l}\text { Broad shoulders } \\
\text { Narrow shoulders }\end{array}$ & $\begin{array}{l}9 \\
9\end{array}$ & $\begin{array}{l}7.3 \\
8.1\end{array}$ & $\begin{array}{l}3.5 \\
2.1\end{array}$ & $\begin{array}{l}6.7 \\
8.9\end{array}$ & $\begin{array}{l}2.8 \\
2.2\end{array}$ & $\begin{array}{l}7.0 \\
6.9\end{array}$ & $\begin{array}{l}3.7 \\
2.9\end{array}$ & $\begin{array}{l}7.5 \\
7.3\end{array}$ & $\begin{array}{l}2.9 \\
1.7\end{array}$ & $\begin{array}{l}7.6 \\
7.9\end{array}$ & $\begin{array}{l}3.1 \\
2.4\end{array}$ & $\begin{array}{l}7.5 \\
6.5\end{array}$ & $\begin{array}{l}2.3 \\
2.4\end{array}$ \\
\hline
\end{tabular}

a See figure 1.

* $\mathrm{P}<0.05$, difference between broad and narrow shouldered subjects

Table 6. Analysis of variance for repeated measurements of the 4 muscles during work with the mouse in different mouse positions and interactions between the mouse positions and gender/height or shoulder breadth. A two-way analysis of variance for repeated measurements with the percentage of the maximal voluntary electrical activity as the dependent variable. (df = degrees of fredom)

\begin{tabular}{|c|c|c|c|}
\hline Source & $\mathrm{df}$ & F-Value & P-Value \\
\hline \multicolumn{4}{|l|}{ Right trapezius muscle } \\
\hline Gender/height/shoulder breath & 1 & $3.345 / 4.282 / 2.721$ & $0.0861 / 0.0551 / 0.1185$ \\
\hline Positions & 5 & $3.421 / 4.136 / 3.907$ & $0.0075 / 0.0022 / 0.0032$ \\
\hline Positions - gender/height/shoulder breath & 5 & $1.783 / 2.743 / 1.707$ & $0.1258 / 0.0244 / 0.1425$ \\
\hline \multicolumn{4}{|l|}{ Left trapezius muscle } \\
\hline Gender/height/shoulder breath & & $1.451 / 1.904 / 1.696$ & $0.2458 / 0.1866 / 0.2112$ \\
\hline Positions & 5 & $1.269 / 1.538 / 1.489$ & $0.2855 / 0.1875 / 0.2026$ \\
\hline Positions - gender/height/shoulder breath & 5 & $1.033 / 1.518 / 0.965$ & $0.4043 / 0.1936 / 0.4444$ \\
\hline \multicolumn{4}{|l|}{ Right deltoid muscle } \\
\hline Gender/height/shoulder breath & 1 & $5.549 / 7.320 / 4.463$ & $0.0316 / 0.0156 / 0.0507$ \\
\hline Positions & 5 & $2.223 / 2.653 / 2.482$ & $0.0600 / 0.0286 / 0.0384$ \\
\hline Positions - gender/height/shoulder breath & 5 & $1.800 / 1.866 / 0.718$ & $0.1222 / 0.1095 / 0.6115$ \\
\hline \multicolumn{4}{|l|}{ Right extensor digitorum muscle } \\
\hline Gender/height/shoulder breath & & $4.011 / 3.509 / 0.098$ & $0.0624 / 0.0794 / 0.7579$ \\
\hline Positions & 5 & $0.775 / 0.950 / 0.973$ & $0.5708 / 0.4536 / 0.4395$ \\
\hline Positions - gender/height/shoulder breath & 5 & $1.519 / 1.436 / 1.857$ & $0.1933 / 0.2205 / 0.1113$ \\
\hline
\end{tabular}

Received for publication: 25 February 1997 